\title{
THE WATER FOOTPRINT OF KATHMANDU METROPOLITAN CITY
}

\section{MOHAN BIKRAM SHRESTHA ${ }^{1}$ \AND UDHAB RAJ KHADKA K $^{1,2}$}

\author{
${ }^{1}$ Central Department of Environmental Science, Tribhuvan University, Kirtipur, \\ Kathmandu, Nepal \\ ${ }^{2}$ Amrit Campus, Tribhuvan University, Kathmandu, Nepal \\ shrmohan5@gmail.com
}

\section{ABSTRACT}

The water footprint is consumption-based indicator of water use. Water footprint is defined as the total volume of both indirect and the direct freshwater used for producing goods and services consumed by individuals or inhabitants of community. There are many studies regarding the direct water use but studies incorporating both direct and indirect water use is deficient. This study tries to estimate total volume of water based on the consumption pattern of different commodities by individuals of Kathmandu Metropolitan city using extended water footprint calculator. The average water footprint of individuals appears to be $1145.52 \mathrm{~m}^{3} / \mathrm{yr}$. The indirect and direct water footprint appears to be $1070.82 \mathrm{Mm}^{3} / \mathrm{yr}$ and $46.59 \mathrm{Mm}^{3} / \mathrm{yr}$ respectively which cumulatively give the total water footprint of Kathmandu Metropolitan City of $1117.40 \mathrm{Mm}^{3} / \mathrm{yr}$. This volume is equal to 2.27 times the annual flow the River Bagmati. The indirect water footprint includes food water footprint of $1055.60 \mathrm{Mm}^{3} / \mathrm{yr}$ or 2.14 times the annual flow and industrial water use of $15.22 \mathrm{Mm}^{3} / \mathrm{yr}$ or 0.03 times the annual flow while the direct water footprint includes domestic water use of $46.59 \mathrm{Mm}^{3} / \mathrm{yr}$ or 0.09 times the annual flow. In food water footprint, cereals consumption shared the highest contribution of $34.82 \%$ followed by meat consumption with share of $32.62 \%$ in total water footprint. Per capita per day water use of inhabitants appears to be 3138 liters which includes water use in food items of 2965 liters, industrial water use of 43 liters and domestic water use of 131 liters. The per capita per day domestic water use is 90 liters more than supplement of 41 liters by the water operator of Kathmandu Valley. Per capita per day domestic water use is already 5 liters more than expected improvement in water supplement of 126 liters per capita per day in 2025 after accomplishment of Melamchi water project. And, it is expected to increase further observing the rapid urbanization of Kathmandu Metropolitan City. The study showed water footprint of individuals is directly related to food consumption behavior, life style and services used therefore it is necessary to initiate water offsetting measures at individual level and water operator to find environmentally sustainable alternatives along with ongoing water project to fulfill demand.

Keywords: Bagmati river, direct water use, consumption pattern, In-direct water use, Melamchi water project, water footprint

\section{INTRODUCTION}

The water footprint is the comprehensive indicator of freshwater resources appropriation, next to the traditional and restricted measure of water withdrawal (Hoekstra et al., 2009, 2011). 
Database on water use traditionally shows three columns of water use: water withdrawals in the domestic, agricultural and industrial sector respectively (Gleick, 1993; Shiklmomanov, 2000; FAO, 2003). Water experts generally account water withdrawals for the different sectors of the economy if asked to assess the water demand of particular area. This technique of water accounting although delivers useful information, this does not tell much about the water actually needed by the people in an area in the relation to their consumption pattern. The fact is that many goods consumed by the inhabitants of an area are produced in other places, which means that it can happen that the real water demand of a population is much higher or lower than the national water withdrawals. Water withdrawals of an area are substantial, but a large amount of the products are being exported for consumption elsewhere (Chapagain \& Hoekstra, 2004).

The water footprint is an indicator of water use that incorporates both direct and indirect water use of a consumer or producer (Hoekstra et al., 2009, 2011). Direct water use refers to the water use at home. The indirect water use of people refers to the water use by others to make the goods and services consumed. It refers to the water that was used to produce for example the food, clothes, paper, energy and industrial goods consumed. The indirect water use can be estimated by multiplying all products (goods and services) consumed by their respective product water footprint. The water footprint of a community is equal to the sum of the individual water footprint of its members (Hoekstra et al., 2009, 2011).

The total water footprint of a community or nation is a useful indicator of a community or nation's share on the global water resources while at an individual level, it is useful to calculate the water footprint as a function of water use, food diet and other resources consumption patterns (Hoekstra et al., 2009, 2011).

Basic amenities like education, facilities, infrastructures, security, job opportunities and transportation are well developed in Kathmandu Metropolitan City (KMC) in comparison to the rest of Nepal. This resulted excessive migration and inflow of people from other parts of the country (ICIMOD, UNEP and MoEST, 2007). Ascending urban growth requires more resources. Water is the foremost requirement of the residents. Therefore, it is vital to estimate amount of water expense by individual or community in every single step not only to meet basic human needs but also for healthy environment and to ensure that the extraction of water from rivers, streams, lakes and aquifers does not affect freshwater ecosystems to perform their ecological functions (Postal, 2000). Therefore, it becomes necessary to relate consumption pattern of individuals and community of KMC for effective management and sustainable use of freshwater systems of KMC or elsewhere beyond from where materials flows in the metropolis.

\section{MATERIALS AND METHODS}

The study based in the quantitative analysis of data relating the consumption pattern of inhabitants attained through questionnaire interviews. The optimal sample size for the study was calculated by following the Arkin and Colton's formula (1963; cited from Sharma, 2000) at $95 \%$ level of confidence and at prevalence or estimated population proportion (p) of 0.5 . A total of 384 households were determined. 


$$
n=\frac{N * Z^{2} * P(1-P)}{N * d^{2}+Z^{2} * P(1-P)}
$$

Where, $\mathrm{n}=$ Sample size

$\mathrm{N}=$ Total Number of households

$Z=$ Confidence level (at 95\% confidence level $Z=1.96$ )

$\mathrm{P}=$ Estimated Population proportion (0.5, this maximizes sample size)

$d=$ Error of $5 \%$ (i.e. 0.05 )

The total sample size determined for the study was re-allocated in each wards on the basis of share in total population of KMC. This made demarcated wards as a strata dividing KMC into 35 different stratas. A least of 2 sample size and the highest of 33 sample size was obtained from the calculation. The inhabitants were purposively selected from each strata for questionnaire survey in order to understand the differentiation in water use and generate the best average water use. Entirely close ended type of questionnaire survey was conducted during the study.

The total water footprint of community was calculated through the gathered information from the questionnaire survey by using Extended Water Footprint Calculator which works under the water footprint calculation equations specified in the Water Footprint Assessment Manual promulgated by Water Footprint Network (Hoekstra et.al, 2009, 2011).

Total water footprint of a consumer $\left(W F_{\text {Cons }}\right)$;

$$
\left.W F_{\text {cons }}=W F_{\text {cons,dir }}+W F_{\text {cons.indir }} \quad \text { [Volume/time }\right]
$$

\section{Direct water footprint}

Direct water footprint is calculated by summation of the water consumption and pollution that is related to water use at home or in the garden. And,

\section{Indirect water footprint}

Indirect water footprint is calculated by multiplying all products consumed by their respective product water footprint. Product water footprint refers to the water consumption and pollution of water that can be associated with the production of that particular goods and services consumed by the consumer.

$$
W F_{\text {Cons, indir }}=\Sigma_{p}\left(C[p] \times W F_{\text {prod }}^{*}[p]\right)_{[\text {Volume/time }]}
$$

Where, $C[p]$ - Consumption of product $p$ (product units/time)

$W F_{\text {prod }}^{*}[p]-$ Water footprint of the product (water volume/product unit). 
The total volume of $p$ consumed will generally originate from different places $x$. The average water footprint of a product $p$ consumed is calculated as:

$$
\left.W F_{\text {prod }}^{*}[p]=\frac{\Sigma_{x}\left(c[x, p] \times W F_{\text {prod }}[x, p]\right)}{\sum_{x} C[x, p]} \quad \text { [Volume/time }\right]
$$

Where, $C[x, p]$ - Consumption of product $p$ from origin $x$ (product units/time)

$W F_{\text {prod }}[x, p]$ - Water footprint of product $p$ from origin $x$ (water volume/product unit)

The water footprint of products consumed is estimated by adding water use of every steps in supply chain. This makes the water footprint of same product/s different. The water footprint of product/s in this study was calculated by following the national average estimates of water footprint of product/s for Nepal by Water Footprint Network.

\section{Water footprint calculation of industrial products}

In the case of industrial products, the virtual-water content is, for practical reasons, expressed in terms of $\mathrm{m}^{3} / \mathrm{US} \$$ instead of $\mathrm{m}^{3} /$ ton. Industrial products show a relatively high heterogeneity and there are often different production methods for one type of product. Since industrial production in a sector as a whole is generally expressed in monetary terms, it is easiest to consider water use in a sector per monetary unit as well (Van Oel et. al., 2008; Hoekstra et.al., $2009,2011)$. The average water footprint of industrial products for Nepal is 20 liters per US $\$$ (Hoekstra et.al, 2009, 2011). Undertaking this as a reference, the industrial water footprint of consumers was determined from a part of gross yearly income (in terms of US\$) which is consumed solely by him/herself.

\section{RESULTS}

Differentiating contribution of components of water footprint, food water footprint stands the highest contributing $94.47 \%$ of total water footprint. Domestic water use contribute $4.17 \%$ and industrial water use stands the least contributing $1.36 \%$ of total water footprint.

Among food water footprint, cereals and meat consumption together contributed more than $67 \%$ in total water footprint. The cereals occupied the largest $(34.82 \%)$ share followed by meat consumption with $32.62 \%$ share in the total water footprint. The reason behind higher contribution of cereals in total water footprint is because cereals are major meal component and is consumed constantly than other food items in Nepalese society thus more the consumption quantity higher is water footprint while in case of meat; large volume of water (virtual water content) is required for producing single kilogram of meat with compare to water amount required for producing other food items. This large virtual water content of meat caused meat as the second largest contributor in water footprint of KMC though majority have low meat consumption amount. Likewise, virtual water content of other animal products such as dairy, eggs etc. is more as meat therefore dairy consumption and egg consumption simultaneously stand third and fourth largest component respectively contributing $9.51 \%$ and $4.89 \%$ share in the total water footprint. Stimulants stands as fifth largest water footprint components contributing $4.68 \%$ share in the total water footprint. Starchy food, fruits vegetables respectively contributed 
$3.42 \%, 3.3 \%$ and $1.31 \%$ in the total water footprint. Sugar consumption and Fat content shares negligible contribution $(0.09 \%$ and $0.01 \%)$ in the total water footprint (figure 1$)$.

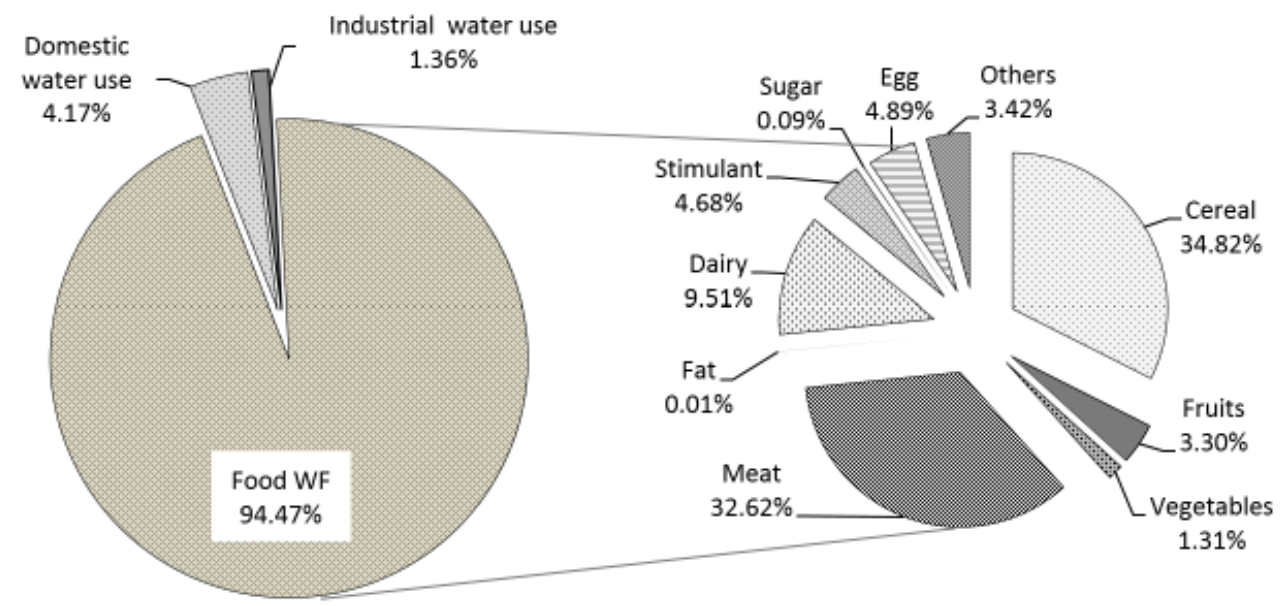

Fig.1. Contribution of components of water footprint .

The water footprint of a community is equal to the sum of the individual water footprint of its members (Hoekstra et al., 2009, 2011) thus based on this principle, the water footprint of KMC is calculated multiplying calculated average water footprint $\left(1145.52 \mathrm{~m}^{3} / \mathrm{yr}\right)$ with population $(975,453)$ of KMC (CBS, 2011). The total water footprint of KMC is estimated to $1117.40 \mathrm{Mm}^{3} /$ $\mathrm{yr}$ which is equal to 2.27 times the annual flow the River Bagmati (average discharge of River Bagmati is $15.6 \mathrm{~m}^{3} / \mathrm{s}$ at Chobhar as per DHM, 1998). This is made up of food water footprint $\left(1055.60 \mathrm{Mm}^{3} / \mathrm{yr}\right)$ which is 2.14 times the annual flow; domestic water use $\left(46.49 \mathrm{Mm}^{3} / \mathrm{yr}\right)$ is 0.09 times the annual flow and industrial water use $\left(15.22 \mathrm{Mm}^{3} / \mathrm{yr}\right)$ is 0.03 times the annual flow (table 1).

The estimated water footprint of KMC when differentiated with perspective of indirect and direct water use, the indirect water use of $1070.82 \mathrm{Mm}^{3} / \mathrm{yr}$ and direct use of $46.59 \mathrm{Mm}^{3} / \mathrm{yr}$ is accounted. Indirect water use accompanies amount of water consumed for production of food and industrial products. When, the total water footprint of $\mathrm{KMC}$ is break down in terms of per person per day consumption, 3138 liters per person per day is accounted. This figure further differentiated as: food items, 2965 liters per person per day; domestic water use, 131 liters per person per day and industrial water use, about 43 liters per person per day. 
TABLE 1. Water footprint of Kathmandu Metropolitan City.

\begin{tabular}{|c|c|c|c|}
\hline \multicolumn{2}{|c|}{ Components of Water Footprint } & Average water footprint & Water footprint \\
\hline \multirow[t]{10}{*}{ Food } & Cereal & 398.88 & 389.09 \\
\hline & Meat & 373.72 & 364.55 \\
\hline & Vegetables & 15.05 & 14.68 \\
\hline & Fruits & 37.82 & 36.89 \\
\hline & Dairy & 108.92 & 106.25 \\
\hline & Stimulants & 53.56 & 52.25 \\
\hline & Fat & 0.06 & 0.06 \\
\hline & Sugar & 1 & 0.98 \\
\hline & Egg & 56.07 & 54.69 \\
\hline & Others (starchy food) & 37.08 & 36.17 \\
\hline \multicolumn{2}{|c|}{ Food water footprint ${ }^{1}$} & 1082.16 & 1055.60 \\
\hline \multicolumn{2}{|c|}{ Domestic water Use ${ }^{2}$} & 47.76 & 46.59 \\
\hline \multicolumn{2}{|c|}{ Industrial water Use ${ }^{1}$} & 15.6 & 15.22 \\
\hline \multicolumn{2}{|c|}{ Total water footprint of KMC } & 1145.52 & 1117.40 \\
\hline \multicolumn{4}{|c|}{${ }^{1}$ Indirect water use, ${ }^{2}$ direct water use } \\
\hline
\end{tabular}

Relating accounted water footprint and resources (food and industrial products) availability and manufacture, it can be easily predicted that KMC is dependent upon resources of other areas of country or abroad since the population of KMC is increasing tremendously and the agricultural land is being filled up with buildings (table 2). This implies KMC is indirectly using water resources of other places in the form of agricultural and industrial products. It is good alternative to release the water stress of $\mathrm{KMC}$ by internalizing water, however it is important to delineate origin of commodities and water availability of importing area as internalizing water from water stress area significantly impact water balance and the ecology of that area thus detailed information of importing area should be considered.

\section{DISCUSSION}

In case of resulted direct water footprint $\left(46.59 \mathrm{Mm}^{3} / \mathrm{yr}\right)$ of $\mathrm{KMC}$ when break down in per day consumption, 128 million liters per day is generated. This equates to 131 liters when further differentiated into per capita per day consumption of KMC. Relating this with per capita per day water (41 liters) supplement of water operator-Kathmandu Upatyaka Khanepani Limited 
(KUKL, 2011), water use exceeds by 90 liters. Melamchi water project is supposed to improve per capita water consumption from 41 liters per capita per day in 2011 to 126 liters per capita per day in 2025 after completion of project (Shrestha, 2012). In fact, water supplement will be inadequate even after completion of this project because the per capita water use have been 6 liters more than expected to improve in 2025. The direct water use of KMC is expected to increase further by observing the population growth trend (table 2) of KMC, therefore it is necessary either inhabitants optimize water use or authorized water operator look for alternative sources and enhance water augmentation schemes like rain water harvesting, water recharge zones etc. to fulfill water demand besides Melamchi water project.

TABLE 2. Population growth trend of Kathmandu Metropolitan City.

\begin{tabular}{|r|r|r|r|}
\hline \multicolumn{1}{|c|}{$\begin{array}{c}\text { Census } \\
\text { Year }\end{array}$} & Population of KMC & $\begin{array}{c}\text { Increased population in 10 } \\
\text { years }\end{array}$ & \% increment \\
\hline 1991 & 427045 & - & - \\
\hline 2001 & 671846 & 244801 & $57 \%$ \\
\hline 2011 & 975453 & 303607 & $45 \%$ \\
\hline
\end{tabular}

Source: CBS, 1991, $2001 \& 2011$

\section{ACKNOWLEDGEMENTS}

We would like to thank Prof. Dr. Kedar Prasad Rijal, Head of Department, and Central Department of Environmental Science, Tribhuvan University for granting us to carry out this study. Immense regards is extended to all inhabitants for their response, time and information during questionnaire survey. We are also thankful to World Wildlife Fund-Nepal (WWF-Nepal) for providing financial support to carry out this work.

\section{REFERENCES}

CBS (2011) National population and housing census 2011 (Village Development Committee/Municipality), Volume 02, Government of Nepal, National Planning Commission Secretariat, Central Bureau of Statistics, Kathmandu, Nepal; pp. 42.

CHAPAGAIN, A K; HOEKSTRA, A Y (2004) Water Footprint of nations, Volume 1: Main report, The value of water research report series No. 16, UNESCO-IHE, Delft, the Netherlands; pp. 52-59.

DEPARTMENT OF HYDROLOGY AND METEOROLOGY (1998) Hydrological record of Nepal: stream flow summary. Kathmandu: HMG/Ministry of Science and Technology/Department of Hydrology and Meteorology. FAO (2003) Food and Agriculture Organization of the United Nations, Rome, Italy.

GLEICK, P H (ed.) (1993) Water in crisis: a guide to the world's fresh water resources, Oxford University Press, Oxford, UK.

HOEKSTRA, A Y; CHAPAGAIN, A K; ALDAYA, M M; MEKONNEN, M M (2009) Water footprint manual: state of the art 2009, Water Footprint Network, Enschede, the Netherlands.

HOEKSTRA, A Y; CHAPAGAIN, A K; ALDAYA, M M; MEKONNEN, M M (2011) Water footprint manual: setting the global standard, Earthscan, London. 
ICIMOD, UNEP and MoEST (2007) Kathmandu Valley environment outlook. International Center for Integrated Mountain Development Center, United Nation Environment Program and Ministry of Environment, Science and Technology/Government of Nepal.

KUKL (2011) Annual report of Kathmandu Upatayeka Khanepani Limited. Kathmandu, Nepal.

POSTEL, S L (2000) Entering an era of water scarcity: the challenges ahead, Ecological Application 10(4): 941-948.

SHARMA, A (2000) Wildlife corridor management: analysis of bio-diversity and socio-economic in buffer zone of Chitwan National Park, Nepal. M.Sc. dissertation, Asian Institute of Technology, School of Environmental Resource and Development, Thailand.

SHIKLOMANOV, I A (2000) Appraisal and assessment of world water resources. Water International 25: $11-32$.

SHRESTHA, M N (2012) Groundwater use in the Kathmandu valley: an analysis of pre- and post-Melamchi scenarios, In Shrestha, S; Pradhananga, D; Pandey V P (eds) Kathmandu Valley groundwater outlook, Asian Institute of Technology (AIT), The Small Earth Nepal (SEN), Center of Research for Environment Energy and Water (CREEW), International Research Center for River Basin Environment-University of Yamanashi (ICRE-UY); 90 pp.

VAN OEL, P R; MEKONNEN, M M; HOEKSTRA, AY (2008) The external water footprint of the Netherlands: quantification and impact assessment, the value of water research report series No. 33, UNESCO-IHE, University of Twente, Enschede, and Delft University of Technology, Delft, the Netherlands; pp.19-23. 